\title{
DETERMINATION OF AND DIFFERENTIATION BETWEEN CASSITERITE AND SILICATE-BOUND TIN IN SILICATE ROCKS CONTAINING TRACES OF TIN
}

\author{
J. Agterdenbos and J. Vlogtman \\ Laboratory for Analytical Chemistry, State University, Croesestraat 77A, Utrecht, Holland
}

(Received 5 December 1971. Accepted 10 March 1972)

\begin{abstract}
Summary-A simple, sensitive and reproducible method is described for the determination of tin in silicate rocks at the ppm level. By applying a selective decomposition it seems possible to differentiate between tin present in the silicate lattice, in readily-accessible cassiterite $\left(\mathrm{SnO}_{2}\right)$ and in cassiterite enclosed in the silicate. The final determination is made by extraction and photometry with phenylfluorone. Results for total tin agree well with those obtained by X-ray fluorescence.
\end{abstract}

TIN OCCURS in many silicate rocks, often in concentrations far below $100 \mathrm{ppm}$. Part of this tin may be a constituent of the silicate lattice ("lattice-bound tin") and another part may be present in the form of cassiterite, tin(IV) oxide, and knowledge of their proportions is useful to geochemists, both for prospecting and for scientific studies.

Some of the methods for the determination of tin in ores have been described and compared by Jeffery. ${ }^{1}$ With methods such as emission spectrography and X-ray fluorescence the total amount of tin is determined without risk of loss due to incomplete destruction, but the results do not differentiate between different types of tin. These techniques are not sensitive enough at the lower levels of tin concentration to be studied here.

Other techniques require a decomposition step. For the final determination several spectrophotometric procedures have been described. After preliminary experiments with Wood's ${ }^{2}$ galleine procedure, which did not give satisfactory results in our hands, we successfully used the method described by Gilbert and Sandell. ${ }^{3}$ It consists of a separation of tin from other elements (especially germanium) by extraction of tin(IV) iodide into benzene, stripping into water and final determination with phenylfluorone. Atomic absorption may also be used, ${ }^{4,5}$ but was not investigated in our study.

The ignition of sample with ammonium iodide at $400-500^{\circ}$ (Caley and Burford ${ }^{6}$ ) quantitatively converts cassiterite into tin(IV) iodide, but lattice-bound tin is not attacked. The silicate lattice may be decomposed by treatment with a mixture of hydrofluoric and sulphuric acids, or perchloric and nitric acids. Cassiterite does not react with these mixtures. In this way "fresh" tin(IV) oxide is formed, and this may then be similarly treated with ammonium iodide to give tin(IV) iodide. "Fresh" tin(IV) oxide is also converted into tin(IV) iodide by hydriodic acid solution; cassiterite is not attacked by this reagent. These differentiations form the basis of the proposed method, which allows tin down to $3 \mathrm{ppm}$ to be determined.

Other decomposition procedures include fusion with sodium peroxide, with potassium pyrosulphate and with a sodium carbonate-sulphur mixture. ${ }^{1}$ None of 
these procedures enables tin present as cassiterite and tin present in the silicate lattice to be differentiated, and they do not seem useful at tin levels below $20 \mathrm{ppm}$. Total tin may be found by attacking the sample with hydrofluoric-nitric acid mixture, and then heating it with ammonium iodide.

Apparatus

EXPERIMENTAL

Destruction unit. Pyrex-tube $2 \mathrm{~cm}$ wide and $25 \mathrm{~cm}$ long fitted with a 40-cm Liebig condenser.

Platinum crucibles. About $20 \mathrm{ml}$ capacity.

Reagents. All reagents were of analytical-reagent grade.

Destruction mixture. Mix two volumes of $40 \%$ hydrofluoric acid with one volume of $65 \%$ nitric acid.

Sulphuric acid, concentrated and 0.25M.

Ammonium iodide.

Twice-distilled demineralized water.

Hydriodic acid, $57 \%$ and $2.5 M$.

Wash liquid. Ammonium iodide $(15 \mathrm{~g})$ dissolved in $20 \mathrm{ml}$ of $2.5 M$ hydriodic acid.

Benzene.

Potassium hydrogen phthalate-hydrochloric acid buffer, $\mathrm{pH} 2 \cdot 6$.

Gum arabic solution, $1 \%$. Discard the solution when it becomes turbid.

Phenylfluarone solution, $0.01 \%$. Dissolve $10 \mathrm{mg}$ of reagent in $1 \mathrm{ml}$ of $1.2 \mathrm{M}$ hydrochloric acid and $100 \mathrm{ml}$ of ethanol. The solution is stable for two months.

Sodium sulphite solution, $0 \cdot 3 \mathrm{M}$.

Standard solution of $\operatorname{tin}(I V) 0.1 \%$, in $3 M$ sulphuric acid. Dissolve $0.50 \mathrm{~g}$ of tin in $20 \mathrm{ml}$ of concentrated sulphuric acid, cool, add $5 \mathrm{ml}$ of $30 \%$ hydrogen peroxide, heat to fumes of suiphur trioxide, cool, and dilute to $500 \mathrm{ml}$, with addition of $65 \mathrm{ml}$ of $18 \mathrm{M}$ sulphuric acid.

\section{Procedures}

Destruction with hydrofluoric-nitric acid mixture. Weigh $1 \mathrm{~g}$ of sample in a weighed platinum crucible and place in a heating-block. Add $1 \mathrm{ml}$ of the destruction mixture, and wait until the violent reaction is finished. Heat gently on an electric hot-plate, and add $1 \mathrm{ml}$ of the destruction mixture. Repeat this until the silicate is dissolved (generally two or three additions are necessary). Heat to dryness and fume the residue three times with $2-\mathrm{ml}$ portions of sulphuric acid. Cool and weigh the platinum crucible. Transfer the residue into a mortar and grind to a fine powder.

Decomposition with ammonium iodide. Transfer to the destruction unit an exactly weighed amount (as much as possible) of the powder resulting from the procedure above and mix it thoroughly with $10 \mathrm{~g}$ of ammonium iodide. Place the lower part of the tube (about $6 \mathrm{~cm}$ ) in an electric oven heated at about $480^{\circ}$. Heat for $1 \mathrm{hr}$, and cool.

Extraction. Transfer $20 \mathrm{ml}$ of $2.5 \mathrm{M}$ hydriodic acid and $5 \mathrm{~g}$ of ammonium iodide into the destruction unit. After dissolution is complete add $7 \mathrm{ml}$ of benzene and extract for $3 \mathrm{~min}$. After both layers have separated, transfer $5 \mathrm{ml}$ of the benzene layer into a $100-\mathrm{ml}$ separating-funnel, add $5 \mathrm{ml}$ of wash liquid and shake for $30 \mathrm{sec}$. After separation, discard the water layer and add $5 \mathrm{ml}$ of $0.25 \mathrm{M}$ sulphuric acid to the funnel. Shake for $2 \mathrm{~min}$ to transfer the tin into the water layer.

Spectrophotometric determination. Transfer the water layer into a $25-\mathrm{ml}$ volumetric fiask, using $3 \mathrm{ml}$ of water to rinse the separating-funnel. Heat in a water-bath to evaporate any benzene not completely removed by the separation. Cool, add some drops of sodium sulphite solution to reduce iodine (formed during the destruction). Add successively $10 \mathrm{ml}$ of buffer, $1 \mathrm{ml}$ of gum arabic solution, and $5 \mathrm{ml}$ of reagent solution. Dilute to the mark, mix, and after $15 \mathrm{~min}$ measure in a $1-\mathrm{cm}$ cuvette at $510 \mathrm{~nm}$ against water as reference. Subtract the absorbance of a blank run on the same day. Prepare a calibration curve in the usual way.

Destruction of "fresh" tin(IV) oxide with hydriodic acid, extraction and determination. Transfer an exactly weighed amount (as much as possible) of the powder from the $\mathrm{HF} / \mathrm{HNO}_{3}$ treatment into a reagent tube with ground-glass stopper. Add $6 \mathrm{ml}$ of concentrated hydriodic acid and heat in a water-bath for $5 \mathrm{~min}$ at $100^{\circ}$. Cool, add $7 \mathrm{ml}$ of benzene, and continue with the extraction and spectophotometric determination.

Note. The procedures given are applicable to samples containing about $3-15 \mathrm{ppm}$ of tin. If more tin is present, smaller samples may be used or a smaller part of the benzene layer may be transferred into the separating-funnel, or a combination of both modifications may be used. The amount of ammonium iodide should be at least ten times the amount of sample and at least $2 \mathrm{~g}$. If less than $10 \mathrm{~g}$ of ammonium iodide are used in the destruction, a correspondingly larger amount of ammonium iodide should be used in the extraction in order to reach the required concentration of this reagent. 


\section{RESULTS}

Tin has been determined in some types of geological sample, such as granite, biotite and muscovite by the proposed method. The results are given in Table I, and compared with those obtained with X-ray fluorescence by van der Weyden. ${ }^{7}$ The precision of the latter results is reported to decrease from about 5 or $10 \mathrm{ppm}$ at the lower tin levels, to about 5 or $10 \%$ at the higher tin-levels.

TABLE I.-RESUltS OF EXPERIMENTS

\begin{tabular}{|c|c|c|c|c|c|c|}
\hline \multirow{3}{*}{\multicolumn{2}{|c|}{ Sample }} & \multicolumn{5}{|c|}{$\begin{array}{l}\text { Amount of } \\
\text { tin, } p p m\end{array}$} \\
\hline & & \multicolumn{2}{|c|}{$\begin{array}{l}\text { X-ray fluor- } \\
\text { escence }\end{array}$} & \multicolumn{3}{|c|}{$\begin{array}{l}\text { Chemical } \\
\text { methods }\end{array}$} \\
\hline & & Total tin & Total tin & $\begin{array}{c}3 \\
\begin{array}{c}\text { Lattice-bound } \\
\text { tin }\end{array}\end{array}$ & $\begin{array}{c}4 \\
\text { Tin present in } \\
\text { cassiterite, } \\
\text { calculated } \\
(2-3)\end{array}$ & $\begin{array}{l}5 \\
\text { Tin in free } \\
\text { accessible } \\
\text { cassiterite }\end{array}$ \\
\hline & granite & 80 & $74 ; 77 ; 75$ & $57 ; 61 ; 62$ & 15 & $3 \cdot 2 ; 2 \cdot 7 ; 2 \cdot 9$ \\
\hline & granite & 15 & $20 ; 22 ; 18 ; 20 ; 18$ & $7 \cdot 3 ; 8.4 ; 7.9 ; 9.0 ; 7 \cdot$ & 12 & - \\
\hline 3 & granite & 5 & $2 \cdot 4 ; 4 \cdot 8 ; 3 \cdot 3$ & $2 \cdot 6$ & 0.9 & - \\
\hline & granite & 18 & $27 ; 27$ & $5 \cdot 1 ; 5 \cdot 3$ & 22 & $2 \cdot 9$ \\
\hline & biotite & $15 ; 20$ & 27 & $4 \cdot 7$ & 22 & $2 \cdot 7$ \\
\hline 6 & muscovite & 70 & 83 & 52 & 31 & 36 \\
\hline 7 & granite & 5 & $2 \cdot 9$ & $2 \cdot 6$ & $0 \cdot 3$ & $1 \cdot 0$ \\
\hline 8 & biotite & $15 ; 15$ & 20 & $9 \cdot 0$ & 11 & $1 \cdot 8$ \\
\hline 9 & granite & 10 & 12 & $3 \cdot 5$ & $8 \cdot 5$ & $1 \cdot 4$ \\
\hline 10 & biotite & $40 ; 40$ & 36 & 11 & 25 & $5 \cdot 3$ \\
\hline 11 & granite & 5 & 11 & $2 \cdot 8$ & $8 \cdot 2$ & $1 \cdot 2$ \\
\hline 12 & biotite & $55 ; 65$ & 58 & 28 & 30 & $2 \cdot 6$ \\
\hline 13 & granite & 5 & $4 \cdot 6$ & $3 \cdot 5$ & $1 \cdot 1$ & $2 \cdot 2$ \\
\hline 14 & biotite & $55 ; 65$ & 62 & 55 & 7 & 14 \\
\hline 15 & granite & 5 & $8 \cdot 2$ & $2 \cdot 8$ & $5 \cdot 4$ & $2 \cdot 2$ \\
\hline 16 & biotite & $30 ; 35$ & 27 & $9 \cdot 0$ & 18 & $2 \cdot 2$ \\
\hline 17 & muscovite & $40 ; 50$ & 35 & 12 & 23 & $2 \cdot 8$ \\
\hline 18 & granite & & $34 ; 30 ; 30$ & 12 & 19 & 11 \\
\hline 19 & biotite & $440 ; 425$ & $463 ; 457$ & $222 ; 229$ & 234 & 73 \\
\hline 20 & granite & & 40 & 14 & 26 & 21 \\
\hline 21 & biotite & $490 ; 470$ & 440 & 345 & 95 & 109 \\
\hline 22 & titanite & - & $32 ; 38 ; 37$ & $8 \cdot 0$ & 28 & 11 \\
\hline
\end{tabular}

The results obtained by treatment with hydrofluoric-nitric acid and subsequent ignition with ammonium iodide are given in column 2 . Results obtained after treatment with hydrofluoric-nitric acid with subsequent reaction with hydriodic acid are given in column 3 and the results obtained by treating the sample with ammonium iodide only are given in column 5 .

\section{DISCUSSION}

\section{Extraction and spectrophotometric determination}

The extraction is promoted by a high concentration of hydrogen ions and iodide ions and by a high electrolyte concentration. The different decomposition procedures led to different concentrations of those species, but with each of the resulting solutions practically the same calibration curves were obtained. The absorbance of the blank increased with time (by $c a .0 \cdot 10-0 \cdot 15$ in two months) and varied from day to day by up to 0.01 . 
Iodine formed from the hydriodic acid and ammonium iodide used for decomposition did not interfere, nor did fluoride up to $0 \cdot 01 \mathrm{M}$, though higher concentrations did. It is important to ensure removal of the bulk of the fluoride if hydrofluoric acid is used.

\section{Decomposition with ammonium iodide}

Caley and Burford ${ }^{6}$ observed that heating of cassiterite with a 10- or 15-fold excess of ammonium iodide resulted in complete removal of both compounds. They suggested that a determination of tin based on this reaction was possible.

Wood $^{2}$ and some others used the method for the determination of cassiterite in soils and sediments. Wood used a twofold excess of ammonium iodide, but neither he nor later investigators reported recovery figures. Little attention has been given to the possibility that the tin(IV) iodide may be lost because of its volatility. An exception is Kerr (quoted by Jeffery ${ }^{1}$ ), who designed a special apparatus to prevent evaporation losses. We performed 25 recovery experiments under various conditions with about $20 \mu \mathrm{g}$ of cassiterite or an equivalent amount of tin(IV) solution, added to granite. The results gave bad recoveries (50-80\% in most cases) if heating was performed in reagent tubes cooled with moistened cotton-wool and in most cases with an ammonium iodide-sample ratio $2: 1$.

Results, given in Table II, were obtained with the procedure described above. In these experiments the cassiterite used was supposed to have a tin(IV) oxide content between 90 and $95 \%$. It was therefore concluded that the recovery was practically quantitative.

TABLE II.-RECOVERY EXPERIMENTS WITH DIFFERENT AMMONIUM IODIDE-SAMPLE RATIOS.

\begin{tabular}{cccc}
\hline $\begin{array}{c}\text { Amount of } \\
\text { granite, } g\end{array}$ & $\begin{array}{c}\text { Amount of } \\
\text { ammonium iodide, } g\end{array}$ & $\begin{array}{c}\text { Ratio, } \\
\text { ammonium } \\
\text { iodide-sample }\end{array}$ & Recovery*, \% \\
\hline 0.200 & $2 \cdot 0$ & $10: 1$ & 90 \\
0.130 & first 1.3 & first $10: 1$ & 91 \\
0.130 & then 0.7 & then $5: 1$ & 90 \\
0.100 & $2 \cdot 0$ & $15: 1$ & 89 \\
\hline
\end{tabular}

* The cassiterite was assumed to contain about $90-95 \%$ tin(IV) oxide. About $20 \mu \mathrm{g}$ of cassiterite were added in each experiment.

\section{Reaction of tin(IV) oxide with hydriodic acid}

It was also found by Caley and Burford ${ }^{8}$ that tin(IV) oxide reacts with concentrated hydriodic acid at $90-100^{\circ}$ as follows:

$$
\mathrm{SnO}_{2}+4 \mathrm{HI} \rightarrow \mathrm{SnI}_{4}+2 \mathrm{H}_{2} \mathrm{O}
$$

Other insoluble oxides do not show any characteristic reactions with this acid. When we treated "fresh" tin(IV) oxide with warm concentrated hydriodic acid, no reaction seemed to occur, but the solid became voluminous. This phenomenon could be explained only by the formation of tin(IV) iodide. Indeed, on shaking the reaction product with benzene the solid disappeared instantaneously and tin was detected in 
the benzene layer. With cassiterite no reaction took place. This difference in behaviour suggested the possibility of differentiation between cassiterite and latticebound tin, because as we saw before, lattice-bound tin may be converted into "fresh" tin(IV) oxide by hydrofluoric-nitric acid mixture.

The time of warming the solution was found to be very important. We performed therefore a number of recovery experiments with different amounts of tin(IV) oxide or tin(IV) solution. They only gave good recoveries when the solution was warmed for not much more than $5 \mathrm{~min}$. Some of the results are given in Table III. The reason for the incomplete recovery was not investigated but it is suggested that a partial reduction to tin(II) takes place.

TABLE III.-INFLUENCE OF THE TIME OF WARMTNG WITH HYDRIODIC ACID ON THE RECOVERY.

\begin{tabular}{|c|c|c|c|c|}
\hline Tin added as & $\begin{array}{l}\text { Amount of } \\
\text { added tin, } \mu g\end{array}$ & $\begin{array}{l}\text { Amount of } \\
\text { hydriodic } \\
\text { acid, } m l\end{array}$ & $\begin{array}{l}\text { Time of } \\
\text { warming, } \min \end{array}$ & Recovery, \% \\
\hline Tin(IV) oxide & $40 \cdot 5$ & 2 & 60 & 68 \\
\hline Tin(IV) oxide & $21 \cdot 9$ & 2 & 30 & 86 \\
\hline Tin(IV) oxide & $17 \cdot 7$ & 2 & 15 & 89 \\
\hline Tin(IV) oxide & $18 \cdot 4$ & 3 & 5 & 98 \\
\hline Tin(IV) oxide & $18 \cdot 4$ & 5 & 5 & 103 \\
\hline Tin(IV) oxide & $565 \cdot 2$ & 5 & 5 & 99 \\
\hline Tin(IV) solution & $19 \cdot 3$ & 2 & $\mathbf{0}$ & 99 \\
\hline Tin(IV) solution & $9 \cdot 6$ & 2 & 2 & 105 \\
\hline Tin(IV) solution & $14 \cdot 3$ & 2 & 5 & 96 \\
\hline Tin(IV) solution & $7 \cdot 2$ & 6 & 5 & 104 \\
\hline Tin(IV) solution & $14 \cdot \overline{3}$ & 2 & 15 & 90 \\
\hline Tin(IV) solution & $19 \cdot 3$ & 2 & 30 & 71 \\
\hline Tin(IV) solution * & $5 \cdot 9$ & 6 & 5 & 102 \\
\hline Tin(IV) solution * & $5 \cdot 9$ & 6 & 5 & 91 \\
\hline Tin(IV) solution * & $5 \cdot 9$ & 6 & 5 & 95 \\
\hline
\end{tabular}

* The tin solution was added to about $1 \mathrm{~g}$ of a granite with known content of lattice-tin. Destruction with hydrofluoric-nitric acid was followed by the treatment with hydriodic acid.

After the treatment with hydrofluoric-nitric acid some hydrofiuoric acid is left in the reaction product and too large amounts of it may interfere. Fuming the residue with sulphuric acid is generally applied to remove hydrofluoric acid but it is a wellknown fact that the resistance to dissolution of many products is greatly increased if they are exposed to high temperatures. Therefore it seemed possible that the fuming might influence the reactivity of the "fresh" tin(IV) oxide. Consequently some experiments were performed with known amounts of tin added to granite, with fuming repeated various numbers of times. The results showed that fuming between one and five times did not significantly change the recovery, which was close to $100 \%$.

\section{Interpretation of the results}

The replicate experiments for the total tin determination (Table I) show a standard deviation of about $1.3 \mathrm{ppm}$ at the $3.5 \mathrm{ppm}$ level ( 3 variates) $2 \mathrm{ppm}$ at the $20-40-\mathrm{ppm}$ level $(n=10)$ and $3 \mathrm{ppm}$ at the 75 -ppm level $(n=3)$. For the lattice-bound tin standard deviations of about $1 \mathrm{ppm}$ at the 8-ppm level $(n=5)$ and $3 \mathrm{ppm}$ at the 60 -ppm level $(n=3)$ were found. The contribution to the total error by the extraction and spectrophotometric procedure depends on the final concentration of the sample 
solution. It varies from about $20 \%$ for $3 \mathrm{ppm}$ to $4 \%$ for $15 \mathrm{ppm}$ and more. The absolute values for the total tin should agree with the $\mathrm{X}$-ray fluorescence results. Within the limits of error expected the agreement is satisfactory, except for sample 18. No explanation for the deviation found here can be given, except for an untraced error in one of the measurements.

The figures in columns 4 and 5 would be expected to be equal. In many cases rather large deviations have been found, however. To explain this, it should be realized that part of the cassiterite may be occluded in the silicate lattice and therefore may be inaccessible to the ammonium iodide if the sample is ignited with this reagent. It is suggested therefore that the differences between the figures given in columns 4 and 5 give the amount of cassiterite which is more or less enclosed in the silicate lattice.

We conclude that for the determination of the total tin, the destruction described here gives good results and that it may be used at much lower concentrations than $\mathrm{X}$-ray fluorescence can. Moreover it may also allow differentiation between the various types of tin present in the rock: tin bound in the silicate lattice, tin present as cassiterite and readily accessible to reaction with $\mathrm{NH}_{4} \mathrm{I}$, and tin present as cassiterite enclosed in the silicate lattice.

For the determination of cassiterite in silicate rocks the procedures using only ammonium iodide probably often give low results, because they do not take account of the fact that part of the cassiterite is enclosed within the silicate lattice.

Acknowledgement-We express our thanks to Drs. C. H. van der Weyden of the Vening Meinesz Laboratorium voor geochemie en mineralogie of this University. He suggested that we do some work on the analysis of tin with a purely chemical method, put at our disposition his results of the $\mathrm{X}$-ray fluorescence measurements and had valuable talks with us on the geochemical problems we encountered.

\begin{abstract}
Zusammenfassung-Ein einfaches, empfindliches und reproduzierbares Verfahren zur Bestimmung von Zinn im ppm-Bereich in Silikatgesteinen wird angegeben. Durch Verwendung eines selektiven Aufschlusses scheint es möglich, zwischen im Silikatgitter eingebautem Zinn, zwischen gut angreif barem Cassiterit $\left(\mathrm{SnO}_{2}\right)$ und im Silikat eingeschlossenem Cassiterit zu unterscheiden. Die endgültige Bestimmung wird mittels Extraktion und Photometrie mit Phenylfluoron ausgeführt. Die Ergebnisse für das Gesamtzinn stimmen gut mit denen der Röntgenfluoreszenz überein.

Résumé-On décrit une méthode simple, sensible et reproductible pour le dosage de l'étain dans des roches aux silicates au niveau de la p.p.m. En appliquant une décomposition sélective, il semble possible de différencier l'étain présent dans le réseau de silicate, dans la cassitérite aisément accessible $\left(\mathrm{SnO}_{2}\right)$ et dans la cassitérite enrobée dans le silicate. On effectue le dosage final par extraction et photometrie à la phénylfluorone. Les résultats pour l'étain total sont en bon accord avec ccux obtenus par fluorescence de rayons $X$.
\end{abstract}

\title{
REFERENCES
}

1. P. G. Jeffery, Chemical Methods of Rock Analysis, pp. 435-445. Pergamon, Oxford, 1970.

2. G. A. Wood, Symposium de exploracion geoquimica, Congresso geologico internacional $X X^{\mathbf{a}}$ Sesión Ciudad de México, 1956, 461.

3. D. D. Gilbert and E. B. Sandell, Microchem. J. 1960, 4, 491.

4. B. Moldan, I. Rubeška, M. Mikšovský and M. Huka, Anal. Chim. Acta, 1970. 52, 91.

5. G. D. Christian and F. J. Feldman, Atom Absorption Spectroscopy, Applications in Agriculture, Biology and Medicine, pp. 403-407. Wiley, New York, 1970.

6. E. R. Caley and M. G. Burford, Ind. Eng. Chem., Anal. Ed., 1936, 8, 114.

7. C. H. van der Weyden, private communication.

8. E. R. Caley and M. G. Burford, Ind. Eng. Chem., Anal. Ed., 1936, 8, 63. 